\title{
舞鶴湾における夏季成層期の流れと水質分布の数值解析 NUMERICAL ANALYSIS OF TIDAL CURRENT AND WATER QUALITY IN STRATIFIED FIELD ON SUMMER IN MAIZURU BAY
}

\author{
三輪 $\quad$ 浩 $^{1} \cdot$ 池野英利 ${ }^{2}$ \\ Hiroshi MIWA and Hidetoshi IKENO
}

1正会員 工博 舞鶴工業高等専門学校准教授 建設システム工学科（†625-8511 京都府舞鶴市白屋234）

2 工博 兵庫県立大学教授 環境人間学部環境人間学科（テ670-0092 兵庫県姫路市新在家本町1丁目1-12）

\begin{abstract}
In order to understand current conditions of water environment and investigate improvement methods for water quality in an estuary, it is important to clarify characteristics of flow field and circulation of nutrients. Maizuru Bay has complex shape that the northern part with bay mouth (North bay) is quite narrow, and the southern part is separated into West and East bays. Toshima is located at the separation zone. Due to this complex structure, the tidal exchange with the Japan Sea is not always enough, and a deterioration of the water quality in the bay has been concerned. In this study, we investigate characteristics of tidal current and distributions of nutrients (COD, DO, nitrogen and phosphorus) in Maizuru Bay through the numerical analysis based on the baroclinic model and the ecosystem model. The flow field of tidal current and the distributions of temperature, salinity and nutrients are simulated in the case of the summer with density stratification.
\end{abstract}

Key Words : estuary, water quality, tidal current, residual flow, nutrient circulation, nitrogen and phosphorus, Maizuru Bay

\section{1. 緒 言}

沿岸水域における水質の悪化は，社会環境や自然環境 にとって深刻な問題となっている. これは人口の密集や 工業化の進展に伴って窒素やリン等の富栄養化物質が水 域に流入することや水質の自然浄化機能が不十分である ことに起因している. とくに，海水の流れが遅く，外海 との交換が活発に行われないような閉鎖性水域では污濁 物質が貯留されやすく，自然浄化による水質の改善が期 待できない場合が多い，このため，何らかの人為的な方 策を講ずることによって水質改善を図る必要がある。そ のためには，まず，閉鎖性水域における流れ場の特性と 富栄養化物質の循環過程を明らかにすることが重要であ る.これまでも多くの閉鎖性水域において流れや水質の 調査が実施されており，場の状況を把握するための貴重 な資料となっている ${ }^{1), 2)}$ 。しかし，複雑な地形を有する 水域では，調査観測データによる現状把握だけでは不十 分な場合が多く，また，将来予測も困難である。このた め，対象とする水域の流れや物質の挙動に関する数值シ ミュレーションを通して種々の検討が行われている11. 京都府の舞鶴湾は典型的な閉鎖性水域で，狭い湾口と 二つに分かれた深い湾奥を有する。このため，海水交換 が活発ではなく，水質の悪化が懸念されている. Daido ら ${ }^{3}$ は舞鶴湾の水質特性を調査するとともに，ボックス モデルを用いて湾内外の全窒素と全リンの収支バランス について検討した，その結果，陸上から流入する全窒素
の約 3 割，全リンの約 2 割が湾外に流出することを示し た. また，いくつかの水質改善法について検討し，その 効果を分析した. ただし，この検討手法では現状分析の 域を出ず，水質の時間変動や将来予測は困難である．舞 鶴湾全体の流れや水質の特性を明らかにするとともに, 水質改善策の検討を含む水質変動の将来予測が可能な研 究アプローチが必要であるが，これまでほとんど行われ ていない，そこで，本研究では，バロクリニックモデル と生態系モデルに基づく流れ場と水質分布に関する数值 シミュレーションを行い，測定結果と比較するとともに 舞鶴湾におけるこれらの特性を明らかにする。解析は夏 の成層期に対して行うこととし，水質指標としてCOD， DO，窒素およびリンを対象とする.

\section{2. 舞鶴湾の概要}

舞鶴湾は京都府北部に位置し，湾北部，湾西部および 湾東部からなる閉鎖性水域である。面積は23.4km²，平 均水深は湾北部が約 $27 \mathrm{~m}$ ，湾西部と湾東部はいずれも約 $10 \mathrm{~m}$ である。朔望平均干満差は約 $50 \mathrm{~cm}$, 波高は小さいた め観測されていない。また，潮流は弱く，流速は海面付 近で0.05 0.1m/s程度である. 湾西部と湾東部の分岐部 にある戸島によって流れが阻害され易く，外海との海水 交換も十分ではない，人口や商業および工業地は西地区 と東地区に集中しており，各種排水は河川や東・西地区 の浄化センターを通して湾内に排出されている（図-1）. 


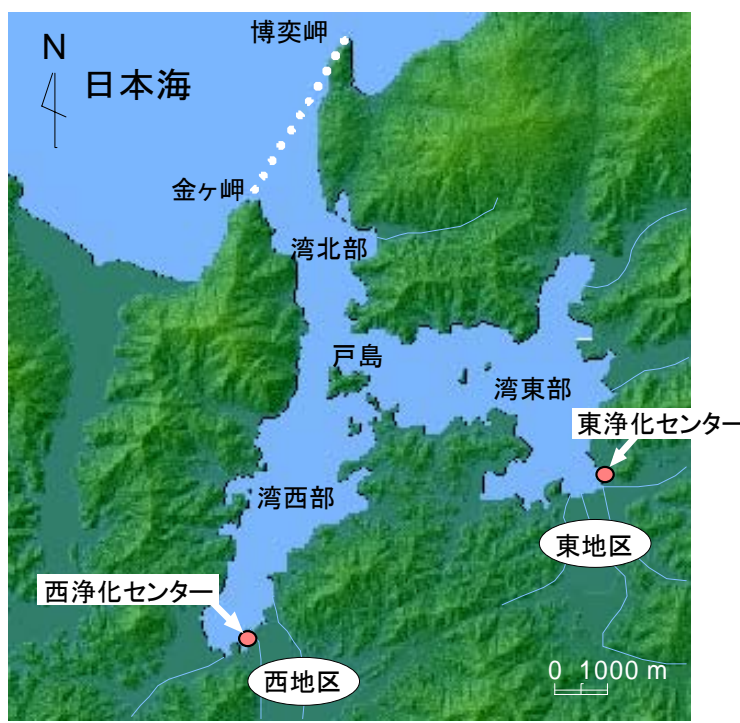

図-1＼cjkstart舞鶴湾

\section{3．基礎式と物質循環モデル}

\section{（1）流れ場の基礎式}

流れの計算に用いる連続式，運動方程式および水位式 を以下に示す．なお，座標軸は平均海面の東向きを $x$ 軸， 南向きを $y$ 軸，鉛直上向きを $z$ 軸とする.

$$
\begin{gathered}
\frac{\partial u}{\partial x}+\frac{\partial v}{\partial y}+\frac{\partial w}{\partial z}=0 \\
\frac{\partial u}{\partial t}+u \frac{\partial u}{\partial x}+v \frac{\partial u}{\partial y}+w \frac{\partial u}{\partial z}=f v-\frac{1}{\rho_{0}} \frac{\partial p}{\partial x}+A_{h}\left(\frac{\partial^{2} u}{\partial x^{2}}+\frac{\partial^{2} u}{\partial y^{2}}\right)+A_{v} \frac{\partial^{2} u}{\partial z^{2}} \\
\frac{\partial v}{\partial t}+u \frac{\partial v}{\partial x}+v \frac{\partial v}{\partial y}+w \frac{\partial v}{\partial z}=-f u-\frac{1}{\rho_{0}} \frac{\partial p}{\partial y}+A_{h}\left(\frac{\partial^{2} v}{\partial x^{2}}+\frac{\partial^{2} v}{\partial y^{2}}\right)+A_{v} \frac{\partial^{2} v}{\partial z^{2}} \\
0=-g-\frac{1}{\rho} \frac{\partial p}{\partial z} \\
\frac{\partial \zeta}{\partial t}+\frac{\partial}{\partial x} \int_{-H}^{\zeta} u d z+\frac{\partial}{\partial y} \int_{-H}^{\zeta} v d z=0
\end{gathered}
$$

ここに，u，v，wはそれぞれ $x, y, z$ 軸方向の速度成分， $f$ はコリオリパラメータ， $\rho_{0}$ は基準密度 $\left(=1,000 \mathrm{~kg} / \mathrm{m}^{3}\right), \rho$ は海水密度，pは圧力， $A_{h} ， A_{v}$ はそれぞれ水平方向およ び鉛直方向の渦動粘性係数，gは重力加速度，Hは基準 面から海底面までの深さである。

さて，基準面から海面までの距離を $\zeta と し ， \rho=\rho_{0}-\Delta \rho$ （ $\Delta \rho$ は密度偏差）とおけば，式(4)より次式が得られる。

$$
p=\rho_{0} g z+\rho_{0} g \zeta-\int_{-z}^{\zeta} \Delta \rho g d z
$$

海水密度は主として水温と塩分によって決まり，これ らはそれぞれ次の拡散方程式で表される。

$$
\begin{gathered}
\frac{\partial T}{\partial t}+u \frac{\partial T}{\partial x}+v \frac{\partial T}{\partial y}+w \frac{\partial T}{\partial z}=K_{h}\left(\frac{\partial^{2} T}{\partial x^{2}}+\frac{\partial^{2} T}{\partial y^{2}}\right)+K_{v} \frac{\partial^{2} T}{\partial z^{2}}+q_{z} \\
\frac{\partial S}{\partial t}+u \frac{\partial S}{\partial x}+v \frac{\partial S}{\partial y}+w \frac{\partial S}{\partial z}=K_{h}\left(\frac{\partial^{2} S}{\partial x^{2}}+\frac{\partial^{2} S}{\partial y^{2}}\right)+K_{v} \frac{\partial^{2} S}{\partial z^{2}}
\end{gathered}
$$

ここに，Tは水温 $\left({ }^{\circ} \mathrm{C}\right) ， K_{h} ， K_{v}$ はそれぞれ水平方向およ び鉛直方向の拡散係数， $q_{\mathrm{z}}$ は日射による水温生成項, $S$ は塩分 $(\mathrm{psu})$ である. なお，海水密度 $\left(\mathrm{kg} / \mathrm{m}^{3}\right)$ は近似的に

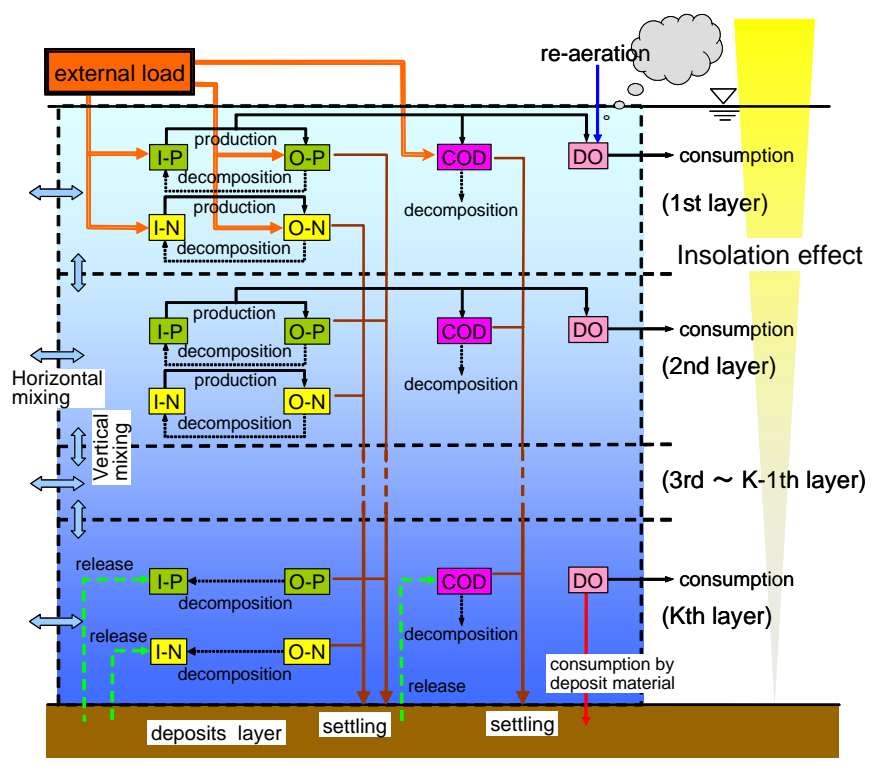

図-2 物質循環モデル

次式で求められる4).

$$
\begin{aligned}
\rho-1000= & 28.14-0.0735 T \\
& -0.00469 T^{2}+(0.802-0.002 T)(S-35)
\end{aligned}
$$

\section{（2）物質循環の基礎式}

物質濃度の変化は生化学反応項を含んだ次の移流拡散 方程式によって表される.

$$
\frac{\partial c}{\partial t}+\frac{\partial(u c)}{\partial x}+\frac{\partial(v c)}{\partial y}+\frac{\partial(w c)}{\partial z}=D_{h}\left(\frac{\partial^{2} c}{\partial x^{2}}+\frac{\partial^{2} c}{\partial y^{2}}\right)+D_{v} \frac{\partial^{2} c}{\partial z^{2}}+R_{c}
$$

ここに，cは物質濃度， $D_{h} ， D_{v}$ はそれぞれ水平方向およ び鉛直方向の拡散係数である. また， $R_{c}$ は物質の生化学 反応式を表す。本研究では水質指標としてCOD，DO, 有機態窒素 (O-N), 無機態窒素(I-N), 有機態リン (O-P) および無機態リン(I-P)を対象とし，湾内におけるこれ らの物質の循環を蔵本・中田占のモデルを基本として,

図-2のようにモデル化した。なお，生化学反応式は Horie ${ }^{6)}$ のデルをもとに以下のように表す.

$$
\begin{gathered}
\frac{d(C O D)}{d t}=\beta G O P-B^{C} C O D-\frac{S^{C} C O D}{h}+\frac{R_{C O D}}{h}+\frac{L_{C O D}}{h \Delta x \Delta y} \\
\frac{d(D O)}{d t}=\gamma G O P-B^{O} C O D-\frac{D B}{h}+A(S D O-D O) \\
\frac{d(O N)}{d t}=G_{N} O N-B^{N} O N-\frac{S^{N} O N}{h}+\frac{L_{O N}}{h \Delta x \Delta y} \\
\frac{d(I N)}{d t}=-G_{N} O N+B^{N} O N+\frac{R_{I N}}{h}+\frac{L_{I N}}{h \Delta x \Delta y} \\
\frac{d(O P)}{d t}=G O P-B^{P} O P-\frac{S^{P} O P}{h}+\frac{L_{O P}}{h \Delta x \Delta y} \\
\frac{d(I P)}{d t}=-G O P+B^{P} O P+\frac{R_{I P}}{h}+\frac{L_{I P}}{h \Delta x \Delta y}
\end{gathered}
$$

ここに，ON，IN，OP，IPはそれぞれO-N，I-N，O-P，I$\mathrm{P}$ の濃度， $G ， G_{N}$ はそれぞれI-PとI-Nによる植物プランク トンの生産速度定数, $B^{O}$ は分解による $D O$ 消費速度, $B^{C}$, $B^{N} ， B^{P}$ はそれぞれCOD，O-NおよびO-Pの分解速度定数, $S^{C} ， S^{N} ， S^{P}$ はそれぞれCOD，O-NおよびO-Pの沈降速度， 


\section{表-1＼cjkstart水質モデルパラメータ}

\begin{tabular}{|c|c|c|c|c|c|}
\hline 反応 & パラメータ & 值 & 反応 & パラメータ & 值 \\
\hline \multirow{10}{*}{ 生産 } & $k_{N}(\mathrm{mg} / \mathrm{l})$ & 2.85 & \multirow{2}{*}{ 分解 } & $B^{N} \quad(1 /$ day $)$ & 0.04 \\
\hline & $\begin{array}{ll}k_{P} & (\mathrm{mg} / \mathrm{l}) \\
\end{array}$ & 0.095 & & $\begin{array}{|ll|}B^{P} & (1 / \text { day }) \\
\end{array}$ & 0.04 \\
\hline & $\beta_{0}$ & 0.5 & \multirow{3}{*}{ 沈降 } & $S^{C} \quad$ (m/day) & 0.072 \\
\hline & $A_{r}$ & 0.06 & & \begin{tabular}{|ll}
$S^{N}$ & (m/day) \\
\end{tabular} & 0.3 \\
\hline & $\kappa(1 / \mathrm{m})$ & 0.5 & & \begin{tabular}{|ll}
$S^{P}$ & (m/day) \\
\end{tabular} & 0.3 \\
\hline & $I_{\text {opt }}\left(\mathrm{kcal} / \mathrm{m}^{2} /\right.$ day $)$ & 2000 & \multirow{3}{*}{ 溶出 } & $R_{\mathrm{COD}}\left(\mathrm{mg} / \mathrm{m}^{2} /\right.$ day $)$ & 44 \\
\hline & $k_{G \alpha 1}(1 /$ day $)$ & 0.59 & & $R_{I N}\left(\mathrm{mg} / \mathrm{m}^{2} /\right.$ day $)$ & 7 \\
\hline & $k_{G \beta 1}$ & 0.0693 & & $R_{I P}\left(\mathrm{mg} / \mathrm{m}^{2} /\right.$ day $)$ & 4 \\
\hline & $\beta$ & 72 & \multirow{2}{*}{$\begin{array}{l}\text { 底泥 } \\
\text { 消費 }\end{array}$} & \multirow{2}{*}{$D B\left(\mathrm{mg} / \mathrm{m}^{2} /\right.$ day $)$} & \multirow{2}{*}{390} \\
\hline & $\gamma$ & 62 & & & \\
\hline \multirow{2}{*}{ 分解 } & $B^{C}(1 /$ day $)$ & 0.05 & \multirow{2}{*}{ 曝気 } & $A \quad$ (1/day) & 0.1 \\
\hline & $B^{O}\left(\mathrm{mg} / \mathrm{m}^{2} /\right.$ day $)$ & 0.024 & & $S D O(\mathrm{mg} / \mathrm{l})$ & 7.23 \\
\hline
\end{tabular}

$R_{C O D}, R_{I N}, R_{I P}$ はそれぞれCOD, I-Nおよび-Pの底泥から の溶出， $L_{C O D}, L_{O N}, L_{I N}, L_{O P}, L_{I P}$ はそれぞれCOD, O-N, I-N，O-PおよびI-Pの流入負荷，Aは再曝気係数，DBは 底泥による消費，SDOは飽和酸素濃度， $\beta$ はCODへの換 算係数, $\gamma$ はOへの換算係数である. Gおよび $G_{N}$ は次式 によって計算される.

$$
G=\mu_{I} \mu_{T} \frac{I P}{k_{P}+I P}, \quad G_{N}=\mu_{I} \mu_{T} \frac{I N}{k_{N}+I N}
$$

ここに， $k_{P} ， k_{N}$ はそれぞれI-P， I-Nの半飽和定数である. また， $\mu_{I}, \mu_{T}$ はそれぞれ照度および水温の効果を表し， 次式で表される77,8).

$$
\begin{gathered}
\mu_{I}=\frac{I}{I_{o p t}} \exp \left(1-\frac{I}{I_{o p t}}\right), I=\left(1-\beta_{0}\right)\left(1-A_{r}\right) Q_{S O} \exp (-\kappa z) \\
\mu_{T}=k_{G \alpha 1} \exp \left(k_{G \beta 1} T\right)
\end{gathered}
$$

ここに, $I$ は水中日射量, $I_{o p t}$ は最適日射量, $\beta_{0}$ は海面 での吸収率， $A_{r}$ はアルベド， $Q_{s o}$ は全天日射量， $\kappa$ は減衰 係数， $k_{G \alpha 1}, k_{G \beta 1}$ は定数である. なお，これらのパラ メータ值は表-1に示されている.

\section{4. 計算方法と計算条件}

本研究では，z方向を一様な層厚に分割し，層間の交 換を鉛直流速で評価する多層レベルモデルを採用した. また， $x-y$ 平面はスタッガードメッシュとし，基礎式は 陽形式で差分化した。メッシュサイズは， $\Delta x$ (東西方 向 $)=\Delta y$ (南北方向 $)=125 \mathrm{~m}, \Delta z$ (鉛直方向 $)=2 \mathrm{~m}$ とし, 東西方 向65分割, 南北方向86分割および鉛直方向20分割とした.

式(2), 式(3)中のコリオリパラメータに用いる緯度は, 舞鶴湾のほぼ中央の $\varphi=35.5$ 度を与えた。 また，風による 海面のせん断力は次式で算定した.

$$
\tau_{s x}=\gamma_{a}^{2} \rho_{a} W_{x} \sqrt{W_{x}^{2}+W_{y}^{2}}, \tau_{s y}=\gamma_{a}^{2} \rho_{a} W_{y} \sqrt{W_{x}^{2}+W_{y}^{2}}
$$

ここに， $\rho_{a}$ は空気の密度， $W_{x}, W_{y}$ はそれぞれ風速の $x$ お よびy方向成分である. なお， $\gamma_{a}^{2}=1.3 \times 10^{-3}$ とした。ささら に，海底面のせん断応力は次式で求めた.

$$
\tau_{b x}=\gamma_{b}^{2} \rho_{0} u_{b} \sqrt{u_{b}^{2}+v_{b}^{2}}, \tau_{b y}=\gamma_{b}^{2} \rho_{0} v_{b} \sqrt{u_{b}^{2}+v_{b}^{2}}
$$

\begin{tabular}{|c|c|c|c|c|c|}
\hline \multirow{2}{*}{ 水域 } & \multirow{2}{*}{ 河川名 } & \multirow{2}{*}{$\begin{array}{c}\text { 流入量 } \\
\left(\mathrm{m}^{3} / \mathrm{sec}\right) \\
\end{array}$} & \multicolumn{3}{|c|}{ 流入負荷 $(\mathrm{mg} / \ell)$} \\
\hline & & & COD & $\mathrm{T}-\mathrm{N}$ & T-P \\
\hline 湾北部 & 大丹生川 & 0.4 & 2.458 & 0.978 & 0.230 \\
\hline \multirow{3}{*}{ 湾西部 } & 伊佐津川 & 3.7 & 0.673 & 0.273 & 0.025 \\
\hline & 高野川 & 1.0 & 2.676 & 0.914 & 0.119 \\
\hline & 福井川 & 0.3 & 2.430 & 0.791 & 0.101 \\
\hline \multirow{5}{*}{ 湾東部 } & 河辺川 & 0.9 & 0.420 & 0.566 & 0.026 \\
\hline & 朝来川 & 0.8 & 1.427 & 0.504 & 0.060 \\
\hline & 志楽川·祖母谷川 & 1.4 & 1.341 & 0.471 & 0.056 \\
\hline & 与保呂川 & 1.2 & 2.374 & 0.814 & 0.109 \\
\hline & 寺川 & 0.5 & 1.711 & 3.020 & 0.429 \\
\hline 湾西部 & 西浄化センター & 0.0324 & 11.2 & 9.8 & 0.26 \\
\hline 湾東部 & 東浄化センター & 0.146 & 17.1 & 40.0 & 2.46 \\
\hline
\end{tabular}

ここに， $u_{b}, v_{b}$ は最下層のメッシュにおける $x$ おび $y$ 方 向の流速成分である. また， $\gamma_{b}^{2}=2.6 \times 10^{-3}$ とした。
表-2 河川および浄化センターからの流入条件 $\left.{ }^{14)}, 15\right), 16$

輻射熱の取り扱いは安芸の方法 ${ }^{9}$ によることとした.

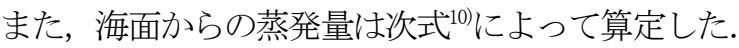

$$
E=\rho_{a} C_{E} U_{10}\left(q_{s}-q\right)
$$

ここに， $C_{E}$ は潜熱の輸送係数， $U_{10}$ は海面上 $10 \mathrm{~m} の$ 風速, $q_{s}$ は海面水温に対する飽和比湿, $q$ は気温に対する飽和 比湿である。

流れ場の計算で用いる水平方向の渦動粘性係数は Richardsonの4/3乗則に従うものとし，次式で与えた.

$$
A_{h}=0.01 \Delta^{4 / 3}
$$

ここに, $A_{h}$ の単位は $\mathrm{cm}^{2} / \mathrm{sec}, \Delta$ は水平方向のメッシュサ イズ (単位 $\mathrm{cm}$ )である。また，水平方向の拡散係数は $K_{h}=5 \times 10^{3} \mathrm{~cm}^{2} / \mathrm{sec}$ した.さらに，鉛直方向の渦動粘性係 数および拡散係数は次の成層化関数によって与えた ${ }^{11)}$

$$
A_{v} / A_{v 0}=\left(1+5.2 R_{i}\right)^{-1}, \quad K_{v} / A_{v 0}=\left(1+10 / 3 \cdot R_{i}\right)^{-3 / 2}
$$

ここに, $A_{v 0}$ は均質流体 (中立安定場) の鉛直方向渦動粘 性係数, $R_{i}$ はRichardson数で, $A_{v 0}=1 \times 10^{-2} \mathrm{~cm}^{2} / \mathrm{s}$ とした。一 方, 物質濃度の計算で用いる水平方向の拡散係数は $D_{h}=$ $1 \times 10^{5} \mathrm{~cm}^{2} / \mathrm{s}$ とし，鉛直方向の拡散係数は先と同様に，次の 成層化関数で与えた。

$$
D_{v} / A_{v 0}=\left(1+10 / 3 \cdot R_{i}\right)^{-3 / 2}
$$

流れ場の計算では，初期条件として流速ゼロと湾口部 の水温，塩分の実測鉛直分布を全ての計算点に与えた. また，舞鶴湾には表-2に示す10本の河川と $2 つ の$ 浄化セ ンターが接続しており，これらからの流入流量を当該 メッシュの第 1 層目に与えた. さらに，開境界を湾口 （図-1：金ヶ岬と博奕岬を結ぶ線上）に設定し，当該メッ シュ点の潮位值を，Naotide ${ }^{12)}$ 用いた三輪・池野 ${ }^{13)} の$ 方 法によって各計算ステップで与えた。流速に関して，閉 境界ではノンスリップ条件を, 開境界では連続条件（勾 配ゼロ）を適用した。一方，物質循環の計算は，初期条 件として湾口部の物質濃度の実測鉛直分布を全ての計算 点に与え，流れ場の計算結果を用いて行った。 また，計 算では表-2に示した流入負荷を流量と同じ計算点に与え た。なお，閉境界，開境界とも水温，塩分および物質濃 度は連続条件を適用した。シミュレーションは，1992年 7月1日から8月 12 日までを対象とし, 日平均の気象条件 を与えて実行した。計算時間間隔 $\Delta t$ は，流れに対しては 1秒，物質循環に対しては180秒とした. 


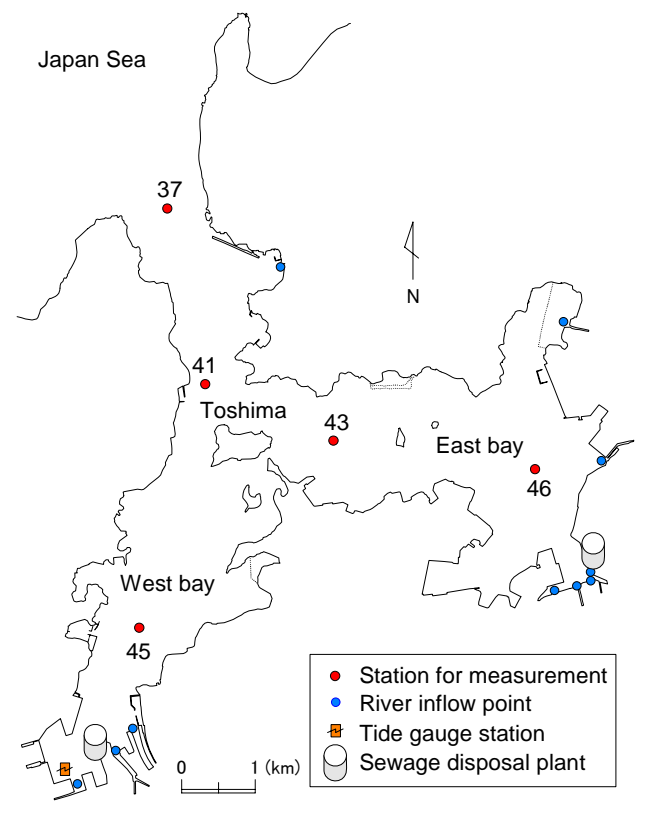

図-3 潮位, 水温, 塩分および物質濃度の測定地点
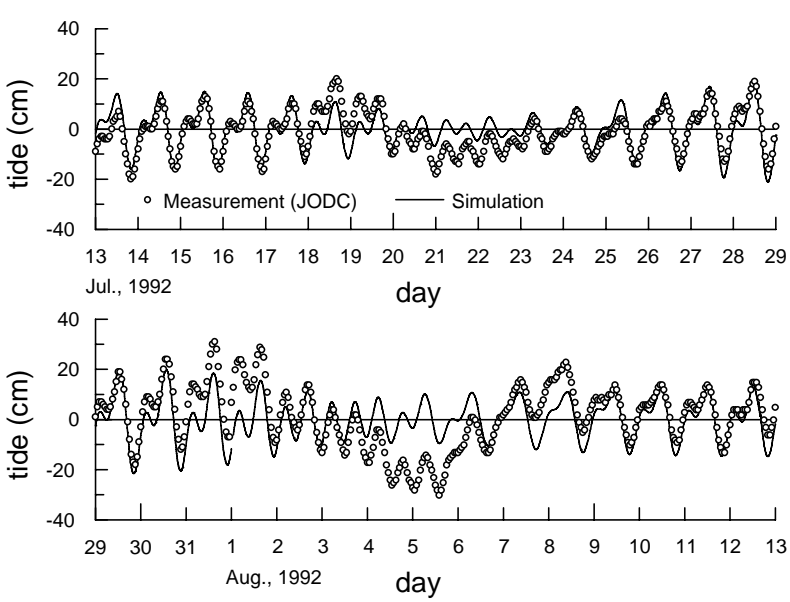

図-4 潮位変動の計算值と測定値 ${ }^{1)}$ の比較

\section{5．計算結果の検証と流れ・物質循環に関する考察}

潮位，水温，塩分および物質濃度分布に関する測定結 果との比較・検討において, 潮位については日本海洋 データセンター1)，水温，塩分および物質濃度について

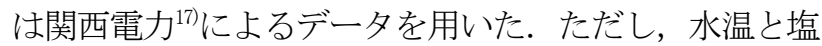
分は1992年8月12日午前9時〜10時28分に測定され，物質 濃度は1992年8月11日 (時間帯不明)に測定されているの で，比較対象の計算結果は両日とも午前10時のものを用 いた．図-3は測定位置を示したもので，河川および浄化 センターからの流入点も併記されている. なお，潮流に ついては測定值が得られなかったので，計算結果のみで その特性を考察する.

\section{（1）潮位変動と流れ場}

図-4は湾西部奥の検潮所における1992年7月13日から8 月12日までの潮位時系列と計算結果を比較したものであ る. 計算結果は潮位の時間変動の傾向をおおむ放表し得 ているといえる。両者が異なっている期間はあるが，干 満の時刻や潮差はほぼ同様である時間帯は多く, 全体と

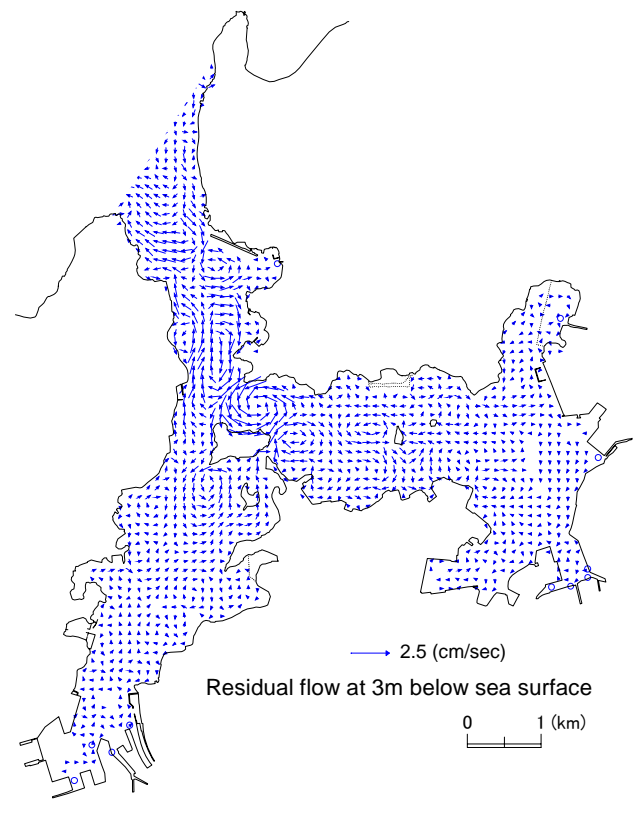

図-5 水平残差流ベクトル（海面下 $3 \mathrm{~m}$ )

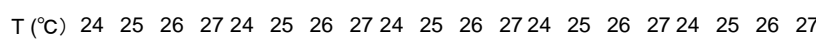

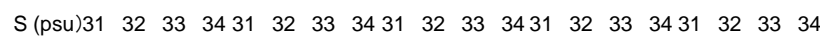

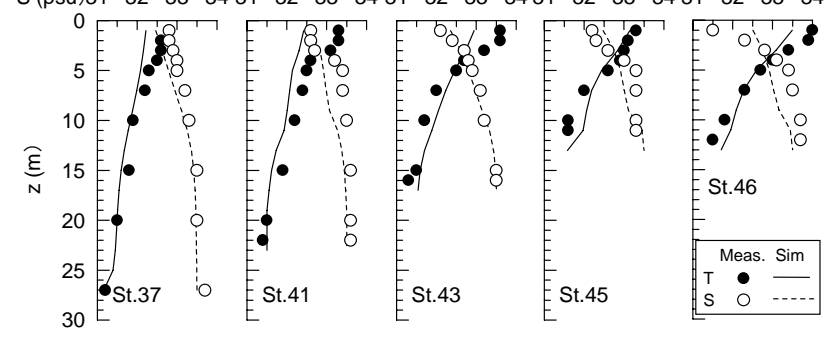

図-6 水温と塩分の鉛直分布の計算值と測定値(7) の比較

しての流れ場の傾向は再現できるものと考える．算定精 度が低い原因は現時点では不明であり, 今後, 気象条件 や計算地形等との関連も考慮して検討寸る必要がある.

図-5は1992年8月 12 日における海面下 $3 \mathrm{~m}$ の残差流べク トルを示したものである. 戸島周辺や湾北部において循 環流の形成が見られる. とくに，戸島の北と南に形成さ れる反時計回りの循環流は, 海面下 $13 \mathrm{~m} て ゙ も そ の$ 存在が 確認されており，湾西部および湾東部の弱い残差流と相 まって，外海との海水交換を抑制している，なお，干潮 時および満潮時の水平方向の流速ベクトルは湾北部では 相対的に大きな流速を示しているが，湾西部および湾東 部では流速はかなり小さいことが分かっており，さらに， 鉛直方向の流速は水平方向の流速に比べて1〜2オーダー 小さいことも確認している.

図-6は図-3に示した各測定点における水温と塩分の鉛 直分布の測定結果と計算結果を比較したものである。 た，図中のSt.番号は図-3の測点番号に対応している. 水 温の測定值は下層加ら上層に向かって徐々に増加してお り，水温成層が形成されていることがわかる．また，海 面付近の水温は湾口から湾奥に向かうほど高く, 水温勾 配 $d T / d z$ も大きくなっている. これは, 湾奥では水深が 浅く，また，外海との海水交換が活発に行われていない ためであると考えられる。一方，塩分は水温とは逆に下 層から上層に向かって徐々に減少しており，この傾向は 


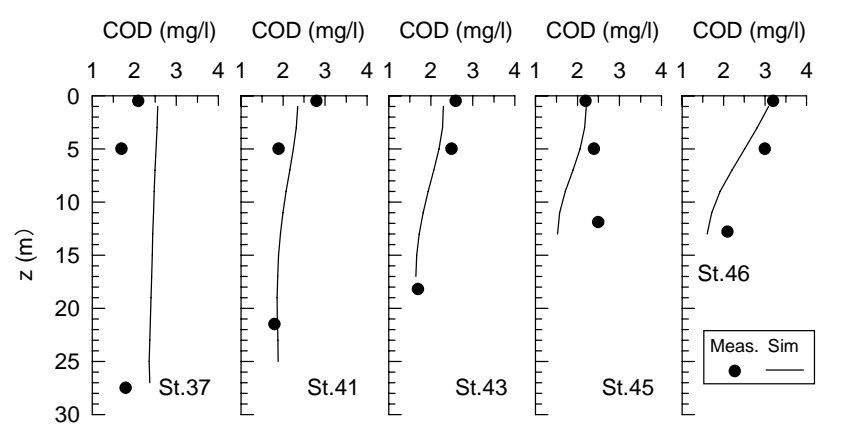

図-7 CODの鉛直分布の計算值と測定値 ${ }^{17)}$ の比較
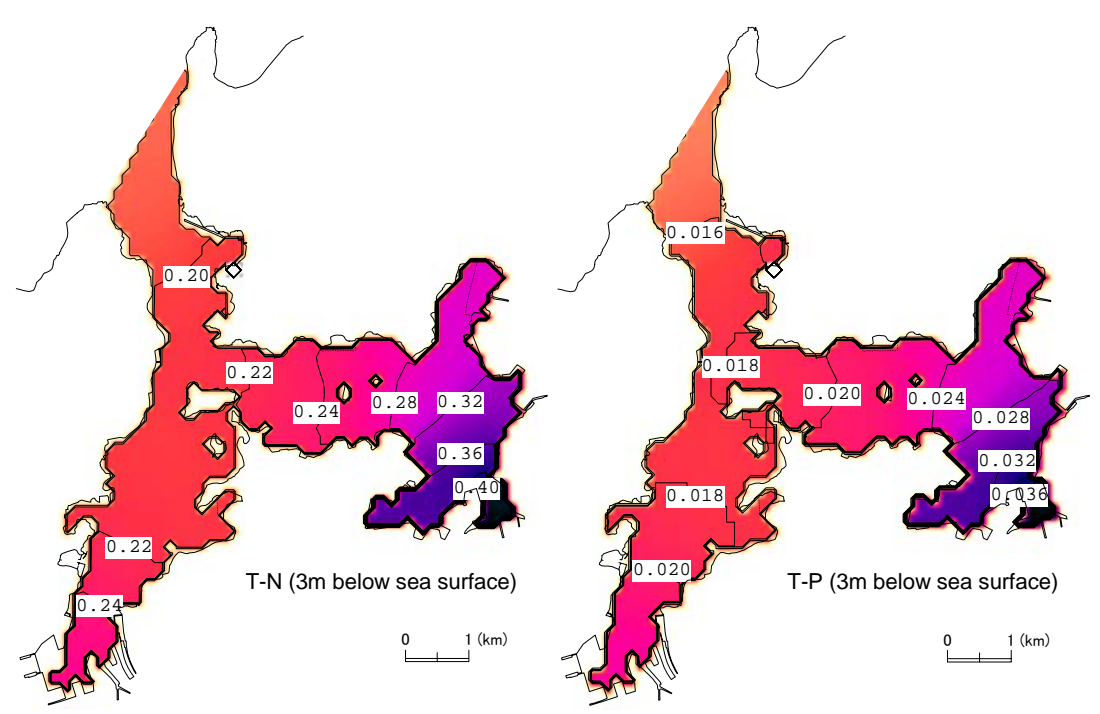

図-9 全窒素および全リン濃度の水平分布（海面下 $3 \mathrm{~m} ）$

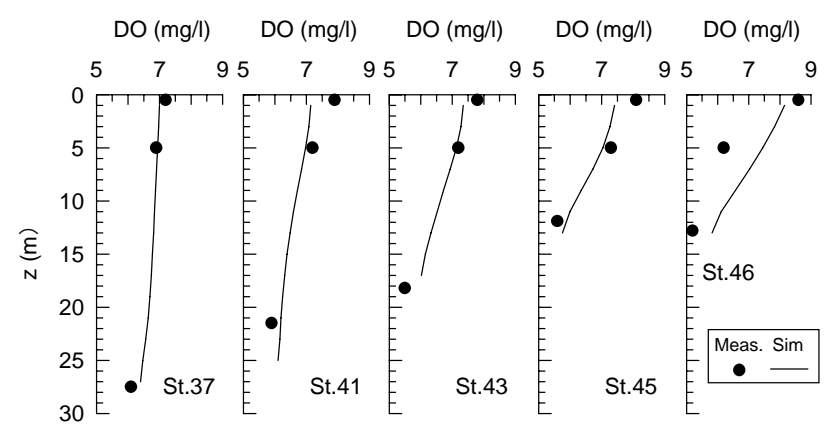

図-8 DOの鉛直分布の計算值と測定値 ${ }^{17)}$ の比較

\begin{tabular}{|c|c|c|c|c|c|}
\hline \multirow{3}{*}{ 水 域 } & \multirow{3}{*}{$\begin{array}{l}\text { 測点 } \\
\text { 番号 }\end{array}$} & \multicolumn{4}{|c|}{ 全窒素 $\left(\times 10^{-1} \mathrm{mg} / \mathrm{l}\right)$} \\
\hline & & 上 & 層 & 下 & 層 \\
\hline & & 測定 & 計算 & 測定 & 計算 \\
\hline \multirow{2}{*}{ 湾北部 } & 37 & 1.9 & 1.9 & 3.2 & 1.7 \\
\hline & 41 & 2.9 & 2.0 & 3.0 & 2.1 \\
\hline 湾西部 & 45 & 3.1 & 2.1 & 2.4 & 2.6 \\
\hline \multirow{2}{*}{ 湾東部 } & 43 & 2.7 & 2.2 & 1.8 & 2.5 \\
\hline & 46 & 3.6 & 3.4 & 2.5 & 2.9 \\
\hline \multirow{3}{*}{ 水 域 } & \multirow{3}{*}{$\begin{array}{l}\text { 測点 } \\
\text { 番号 }\end{array}$} & \multicolumn{4}{|c|}{ 全少ン $\left(\times 10^{-2} \mathrm{mg} / \mathrm{l}\right)$} \\
\hline & & \multicolumn{2}{|c|}{ 上＼cjkstart層 } & \multicolumn{2}{|c|}{ 下 層 } \\
\hline & & 測定 & 計算 & 測定 & 計算 \\
\hline \multirow{2}{*}{ 湾北部 } & 37 & 1.4 & 1.5 & 1.8 & 1.5 \\
\hline & 41 & 1.9 & 1.8 & 2.0 & 2.1 \\
\hline 湾西部 & 45 & 2.5 & 1.8 & 2.6 & 2.8 \\
\hline \multirow{2}{*}{ 湾東部 } & 43 & 2.2 & 1.9 & 1.8 & 2.5 \\
\hline & 46 & 3.0 & 2.9 & 3.8 & 3.0 \\
\hline
\end{tabular}

湾口部に比べて湾奥の方が強いことがわかる。この原因 は明らかになっていないが，湾への淡水の流入が関係し ている可能性がある. 水温の計算結果は, 海面付近の水 温が湾口から湾奥にかけて高く, 水温勾配が増加する傾 向は再現されている。しかし，より厳密には海面近傍で は算定精度が低下しており，今後の検討課題である。ま た，塩分については湾東部(St.46) を除いて測定值の傾向 を再現している．なお，湾東部については淡水流入に影 響についてさらなる検討が必要である.

\section{（2）物質濃度分布}

図-7はCODの鉛直分布の測定結果と計算結果を比較し たものである．両結果とも上層 (0-5m程度) のCOD濃度 は湾奥から湾口に向かって次第に減少寸る傾向にある.

また，湾東部(St.46)の上層の濃度はかなり高い值を示し ている.これは，表-2に示したように，主として湾奥に ある東浄化センターからの排水が高いCOD濃度を示して いることに起因している. なお，西浄化センターからも 比較的高濃度の排水があるが，湾への流入量が少ないた め，湾西部のCOD濃度は必ずしも高くない，一方，下層 (13m程度)における濃度は上層よりもかなり低い，以上 のことから，浄化センターからの高濃度なCOD值を示寸 流入水は主として湾口に向加て水平方向に移流・拡散 していると考えられる.

図-8はDOの鋁直分布の測定結果と計算結果を比較し たものである，同図より，上層のDO濃度は湾北部より
も湾西部や湾東部の方が高い值を示していることがわか る. これは湾口から湾奥に向かうにつれて水深は浅くな り, 流れも遅いため, 水温が上昇しや寸く, また, 後述 するように窒素やリンの濃度も湾奥の方が比較的高く, これらによって生物活動が活発になるためであると考え られる.ただし, 最適水温, 最適栄養塩濃度の影響も受 けるので，より厳密な検討のためには植物プランクトン を特定し，これらのパラメータ值を明らかにする必要が ある。なお， $\mathrm{DO}$ 濃度はCOD濃度の増加に伴って低下寸 るが，ここで扱った場においてはDOの生成が消費より も卓越したものと推察される。一方，海底面付近のDO 濃度は湾奥に向かって徐々に低下しており, その結果, 濃度の鉛直分布は湾北部では一様に近く, 湾奥で比較的 大きな勾配を示す。なお，DO濃度の低下は底泥での消 費が活発であり，これが湾奥でより顕著であることを示 している.

図-9は，海面下3mにおける全窒素および全リンの濃 度の水平分布の計算結果を示したものである. 東西の浄 化センターから窒素やリンを高濃度に含む水が排出され るとともに，河川からも湾内濃度を超える窒素やリンの 流入があるため，湾北部に比べて湾奥において高い值を 示しており，この傾向はとくに湾東部で顕著であること がわかる。これらの濃度は湾奥から湾口に向かうにつれ て低下寸るが，湾東部では高濃度な状態が維持されてい る. 図-3に示された各測定地点における測定值と計算值 の比較を表-3に示す．表中，上層は測定值については海 

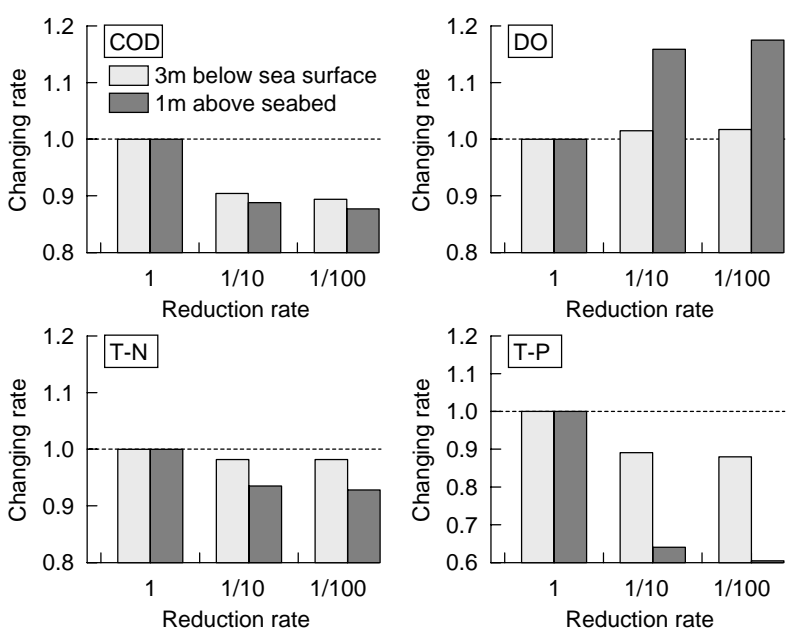

図-10＼cjkstart底泥による内部負荷の削減効果（St. 46）

面下 $0.5 \mathrm{~m}$ ，計算值については海面下 $1 \mathrm{~m} の$ 位置であり， 下層は両者とも海底面上 $1 \mathrm{~m}$ の位置である，測定值を見 ると, 湾北部の下層の窒素を除いて, 窒素, リンとも湾 北部に比べて湾西部や湾東部の方が相対的に高濃度の傾 向にある．計算値はこのような傾向を示してはいるもの の, 窒素については湾北部下層で大きな誤差が見られる. 一方，リンについての相対誤差は窒素よりも小さいが， 主に上層において測定值に比べて若干低い值を示してい る. 計算精度については, 実測データの蓄積とモデル解 析を並行して進めながらその向上を計る必要がある。

窒素やリンの高濃度域の形成は, これらを高濃度に含 む流入水だけでなく，上げ潮および下げ潮の時でも湾西 部と湾東部の潮流はかなり弱いために, 海水交換が効果 的に行われないことにも起因している．窒素やリンは湾 奥において非常に緩やかに移流・拡散しているので，こ れらの削減対策はこのような場所に対して重点的に実施 することが効果的であるといえる.

最後に，本研究では底質の議論は行っていないが，底 泥からの物質の溶出も湾内の濃度に影響を及ぼしている ことが予想される，そこで，底泥からの内部負荷量の削 減が水質に及ぼす影響について若干の検討を行う。図一 10は覆砂や浚渫を想定して，表-1の溶出および底泥によ る消費に係るパラメータ值を1/10と1/100にした場合の， 1992年8月 11 日の湾東部 (St.46) におけるCOD，DO，窒 素およびリンの変化を示したものである．内部負荷の削 減効果は上層まで及び，しかも，DOは顕著に増加する ことがわかる。 また，底泥付近のリン減少率も高い。他 の地点でも同様の傾向を示したが，水深が浅い湾奥の方 が高い効果が得られた。 今後は，底質による内部負荷プ ロセスを検討し，その影響を明らかにする必要がある.

\section{6. 結 言}

本研究では，バロクリニックモデルと生態系モデルに 基づく数值シミュレーションを通して，舞鶴湾における 夏季成層期の流れ場と物質分布の特性に関する検討を 行った. 本研究で得られた結果を以下に要約する.

（1）戸島の北と南において，反時計回りに循環する残差 流が形成される．また，潮流は戸島によって阻害される
ため, 湾西部や湾東部ではかなり弱、これらのため, 外海との海水交換は活発に行われない.

(2) 水温および塩分の計算結果は鉛直方向の変化傾向を 再現することができた．密度は水温と塩分によって近似 的に求めることができるので, 密度の鉛直方向の変化傾 向も再現できているといえ, 成層状態の計算が可能であ ることが示された.

（3）COD，DOとも上層の濃度は湾北部から湾奥に向か うにつれて徐々に増加する. 前者は浄化センターからの 流入水質の影響であり, 後者は水温上昇によるDO生成 の促進によるものであると考えられる.

（4）窒素およびリンの上層濃度の実測值は湾北部に比べ て湾西部や湾東部奥の方が高く, とくに湾東部奥で顕著 である. このような傾向は計算結果によっても示された が，相対誤差はとくに窒素で大きく，算定精度について は今後の課題として残された.

\section{参考文献}

1）日本海洋データセンター(JODC), http://www.jodc.go.jp/

2）公共用水域の水質測定結果，環境省総合データベース, http://www.env.go.jp/doc/

3) Daido, A., Miwa, H. and Ikeno, H.: Transmission of nitrogen and phosphorus in the Maizuru Bay and proposal of improvement method for water quality, Environmental Hydraulics, A.A.Balkema Publishers, pp. 555-560, 1999.

4) 中辻啓二 : 大阪湾における残差流系と物質輸送, 水工学 シリーズ，土木学会，第30号，A9，1994.

5）蔵本武明, 中田喜三郎：物質循環モデル, 漁場環境容量, 第 6 章, 恒星社厚生閣, 1992.

6) Horie, T.: Modeling for the Prediction of the Effect of Sea Bed Sediment Treatment on the Improvement of Ecological Conditions and Seawater Quality, Report of Port and Harbor Research Institute, Vol. 26, No. 5, pp. 175-214, 1987.

7) DiToro, D., O’Conner, D.J. and Thomann, R.V.: A Dynamic Model of the Phytoplankton Population in the SacramentoSanjoaquin Delta, Advances in Chemistry Series, American Chemical Society, Vol.131, pp.131-180, 1971.

8）古川恵太，細川恭史 : 浅場の窒素収支を考慮した 3 次元 物質循環モデルの構築と計算事例, 港湾技術研究所報告, 第33巻，第3号，pp. 27-56, 1994.

9）安芸周一：貯水池濁水現象，水工学シリーズ，土木学会， 第11号, pp. A-1-A-26, 1975.

10）近藤純正 : 水環境の気象学 一地表面の水収支・熱収支 一, 朝倉書店, 第 2 章, 2000.

11） 中辻啓二, 許 再寧, 室田 明: 三次元表層密度流の数 值実験，土木学会論文集，No. 434/II-16，pp. 19-28，1991.

12) Naotide, Nao.99b tidal prediction system http://www.miz.nao.ac.jp/staffs/nao99/index_En.htm

13） 三輪 浩, 池野英利 : 閉鎖性海域の潮流解析における開 境界条件としての潮位変動の設定法と播磨灘への適用, 応用力学論文集, 土木学会, Vol.10, pp.873-879, 2007.

14）舞鶴港港湾計画資料（その 2）， 1996.

15）舞鶴市役所 : 東西浄化センターの処理水質について，舞 鶴湾水質改善検討資料, 1997.

16）舞鶴工業高等専門学校調査資料，1994（未公開）.

17）関西電力: 舞鶴発電所 修正環境影響調査書, 1995.

(2007.9.30 受付) 